\title{
メタファーの世界を媒介としたユーザー主体による協働の設計プロセス 京都市洛央小学校ブックワールドデザインプロジェクトを対象として

\author{
COLLABORATIVE DESIGN PROCESS WITH USERS THROUGH A METAPHORICAL WORLD
}

A case study on BOOK WORLD DESIGN PROJECT in Rakuo elementary school of Kyoto

\author{
酒谷粋将*, 高木雄貴 ${ }^{* *}$, 高田雄輝 $* * *$, 門内輝行**** \\ Suisho SAKATANI, Yuki TAKAGI, Yuki TAKATA \\ and Teruyuki MONNAI
}

\begin{abstract}
This study aims to clarify how a world of metaphor as a method of collaborative design involves users into an architectural design process. We organized BOOK WORLD PROJECT in Rakuo Elementary School of Kyoto and conducted some workshops participated by about 90 students. The students generated a lot of ideas for their new Book World in the workshops. In this paper, firstly we described the process and what students ideated. We made 3 metaphorical worlds of Book World based on their ideas. Secondly we analyzed the process of developing of the plans through 3 worlds and how the metaphorical worlds effect on students' minds. As a result, we revealed that a metaphorical world activates students' thinking processes and support them to generate new ideas. In addition, we make a point that the metaphorical world makes students more proactive in participating in the design process and making the world of their Book World.
\end{abstract}

Keywords: metaphor, user participation, world making, design process, workshop メタファー, ユーザー参加, 世界制作, 設計プロセス, ワークショップ

\section{1. はじめに}

\section{1 研究の背景と目的}

変化の著しい現代社会における問題はその複雑さゆえに解決す ることが困難を極める。それに伴って 1960 年代に始まった設計方 法の研究を取り巻く状況も、大きな変化を見せている。すなわち、 (1)「技術的合理性」(technical rationality)に根ざして問題解決をはかる いわゆるシステマティックな設計方法によっては、現実の複雑で不 安定な問題にうまく対処できないことが明らかにされ、(2)状況との 対話を通して柔軟に設計をす寸める設計主体に焦点を結び、その設 計行為のありかたをふまえて設計方法を探求する「新しい人間主義」 (new humanism) の試みがさまざまなかたちで展開されるようにな

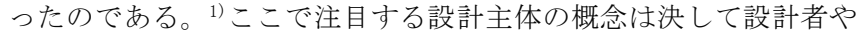
技術者だけではなく、クライアントやユーザーといった多くの主体 を必然的に含むこととなる。また多種多様な設計主体の協㗢による 設計においては、設計行為は単に計画を一つにまとめ上げることで はなく、同時に主体同士が十分なコミュニケーションを行い、互い の合意を形成するプロセスとして理解しなければならない。特に公 共施設やパブリックスペースのデザイン等、多くの多様な主体が関 係することで社会的なプロセスが展開される設計に関しては「参加 によるデザイン」(participatory design) という枠組みで実践的な試み
も交えながら、古くから研究の対象となってきた。こうした協働に よる設計においては設計プロセスそのものがデザインの対象ともな りうるのであるが、その際、設計主体同士のコミュニケーションの 媒介道具となる「設計言語」(language of designing)について理解を深 めることが必要不可欠となる。特に非専門家であるユーザーなどが 複雑な問題を含む事柄を設計対象として扱わ衩ばならない場合には、 それを上手く扱うための手段として、専門的用語ではない新たな設 計言語が求められることになる。

本稿でも上記のような多くの多様な主体が関係するデザインを 対象に、そのプロセスの中で用いる設計言語の中でも特に、類似性 に基づいて既知の事柄を通して未知の事柄を理解するプロセスとし て捉えられる「メタファー (隠喻)」(metaphor)の概念とその言語に 着目し、多様な設計主体が状況との対話を重禅、最終的な合意形成 に至るまでのプロセスで、それが設計言語としていかなる役割を担 っているかについて理解することを目的とする。

\section{2 既往研究と本稿の位置づけ}

筆者らはこれまでにも建築設計におけるメタファーの研究を継 続的に進めてきている。 ${ }^{23) 4}$ (3) ししこれらの研究は主にプロフェッ ショナルとしての設計者ないしはそれに準ずる建築系学生の設計プ ロセスに焦点を絞ったものであった。それに対して本稿では、ユー

\footnotetext{
* 京都大学大学院工学研究科建築学専攻 研修員 · 博士 (工学) 日本学術振興会特別研究員 PD

** (株)日本設計 修士 (工学)

*** (株) 竹中工務店 修士(工学)

**** 京都大学大学院工学研究科建築学専攻 教授・博士 (工学)
}

\author{
Researcher, Dept. of Architecture and Architectural Engineering, Graduate School of \\ Engineering, Kyoto Universty, Dr. Eng. \\ JSPS Research Fellow \\ NIHON SEKKEI, INC., M. Eng. \\ TAKENAKA CORPORATION, M. Eng. \\ Prof., Dept. of Architecture and Architectural Engineering, Graduate School of \\ Engineering, Kyoto University, Dr.Eng.
}


ザーの立場や設計者とユーザーとの相互作用に注目し、多様な主体 に開かれた設計プロセスにおけるメタファーについて見ていく。

前述の通り、参加によるデザインについてはこれまでにも多くの 研究と実践がなされている。有名なものとしては H. Sanoff $\mathrm{f}^{5)}$ にる ものがある。彼は建築・都市のデザインプロセスに住民らが参加す るために、「デザインゲーム」(design game)を始めとする協働による デザインの手法を開発し、その実践を通して長年まちづくりの活動 を展開している。またランドスケープアーキテクトの L. Halprin ${ }^{6}{ }^{6}$ は 多くの人々が無秩序でなく生産的にグループとして共同し、そのプ ロセスの中に身をおきながらもプロセス全体が見えるようにするこ とで、個人と集団の創造性を高め、様々な問題を解く方法として、 資源(resources)、スコア(score)、評価活動(valuaction)、パフォーマン ス(performance)で構成される RSVP サイクルを提唱し、住民の参加 を通したまちづくりの手法を開発した。本研究ではそうした協働的 デザインを支援する方法の基礎的概念としてメタファーを取り上げ、 具体的なワークショップにおける事例においてメタファーを用いた 手法の効果を検証することで、その実践的価值を明らかにする。

また国内における研究として、参加の段階を協働のレベルまで高 め、より深い参加を実現するまでのプロセスを扱った近藤 ${ }^{7)} ら の$ 研 究がある。本研究においてもそうした形式的参加を超えた参加者の 主体性を伴う深い参加としての協働を目指すが、メタファーが本来 的に持つ認知的メカニズムと、設計主体の主体性形成のプロセスと の関係について論じる。そのためにもデザインの中で扱われる具体 的な意見やアイデアの内容に踏み込んだデザインプロセスの分析を 行う必要がある。世田谷まちづくりセンターがデザインゲームを使 ったワークショップ 8)を通して行った住民参加によるデザインの事 例では、予め用意された(1)目標カードと (2)空間タイプ、(3)公園につ くりたいものリスト、から住民それぞれが望むものを選び出して公 園をつくる、という手順でデザインゲームが行われた。このうち(2) の配置や構成を決める空間タイプの表現には、非専門家にもわかり やすい「オムライス」型や「ホットケーキ」型等のメタファーの言 語が使用された。本プロジェクトでは空間タイプに限らず、デザイ ンの対象全体をメタファーで捉え、子どもたちが深く対象に入り込 み、積極的にデザインを展開できるようにすることを狙いとする。

最後に本稿におけるメタファーの概念の扱いについては、これま での研究と同じく G. Lakoff and M. Johnson ${ }^{9}$ の理論や D.Gentner ${ }^{10)} の$ 「アナロジー (類推)」(analogy) の理論に基づいている。注1)

\section{3 研究の方法}

本稿では京都市立洛央小学校の図書スペースのデザインを小学 生の子供たちを中心とした多様な主体による協㗢で行った「京都市 洛央小学校ブックワールドデザインプロジェクト」を事例として、 その後のデザインの原動力となる豊富なアイデアを子どもたちが生 成した初期段階から最終案の実現に至るまでのプロセスを追ってい く。本プロジェクトは計 4 回のワークショップで構成されるが、筆 者らは専門家としてそこに参加し、子どもたちとともにブックワー ルドの設計に携わると同時に、メタファーの概念を応用した設計手 法を活用しながら、如何にして子どもたちを中心とした多様な主体 をこのプロジェクトに巻き込み、それぞれの主体が自身の手で対象 を形作っているという実感を持ちながらデザインプロセスに主体的 に参加することを促せるかを考え、各ワークショップやプロジェク
ト全体の運営方法にも慎重に検討を重礼た。本稿では以上のような 一連のデザインプロセスの分析を通して、多様な主体の協働のプロ セスにおけるメタファーの仕組みを明らかにする。注2) 注3)

\section{2. ユーザーとの協働による設計}

\section{1 ユーザーの参加}

前章で述べたような対話によるデザインというデザインの観点 にたつならば、その対話の相手となるデザイン対象のおかれる状況 を、設計主体がよく観察し理解することがより豊かなデザインの創 造を導くことになるだろう。そのためには自身の要求を熟知してい るユーザーがデザインプロセスに参加しながら行う、ユーザー参加 によるデザインが不可欠となる。11

そもそも本来的には、住宅を建てる意志を持ったクライアントが 建築家にその設計を依頼するように、大きな視点から見れば専門家 としての設計者も一連のデザインの活動に参加していると見ること もできる。そのように考えるとユーザー参加によるデザインは、決 して従来の専門家としての設計者による閉じた設計プロセスの中に 単にユーザーという設計主体が追加されることを意味するのではな く、参加する設計主体が互いの役割を認識した上で対話を重ねてい く協㗢によるデザインとして理解すべきであると考えられる。こう した多くの主体が関係するデザインプロセスの構造は必然的に複雑 になるが、その中でどのように各主体が活発なコミュニケーション を行い、デザインを進めていくかというプロセス自体もまたデザイ ンの対象となるのである。12) そうして設計対象の範囲が広がるとと もに専門家としての設計者には新たな設計者としての役割が求めら れることになるのである。13)

\section{2 参加の概念について}

C. Alexander ${ }^{14)}$ は参加によるデザインの意義として、ユーザーは 誰よりも自分の要求を熟知しているということに加え、参加が人々 の連帯を強め、彼らをその世界の中に包多込むことを挙げている。 また H. Sanoff も参加によるデザインが、デザインの成果物に効果を もたらすデザイン方法のひとつである以上に、そのプロセスを通し て人々がコミュニティを形成することを支援するものであることに その意義を見出している。

こうしたことを考えると、ユーザー参加の概念にも単なる設計条 件としての要求を設計者がユーザーから引き出すというものから、 ユーザーが設計に関するあらゆる決定権を握るようなものまで、い つくかの段階があると考えることができる。

例えば F.D.Becker ${ }^{15)}$ は参加によるデザインに、(1)インプット・フ イードバック（人々は決定権を持たず、意見のみを言う。）(2)コント ロール（どの案が選択されるかを決定する。）(3)遂行（選択された案 を自らの手でつくり出す）といった区別される型があることを示し た。また、より一般的な市民参加の類型化とし図 1 に示す S.R.アー ンスタイン ${ }^{16)}$ の市民参加の八階梯」が有名である。

以上のような参加の概念を標榜すると、一言に参加と言っても 様々な相のものが存在することがわかる。そこでより深く、かつ主

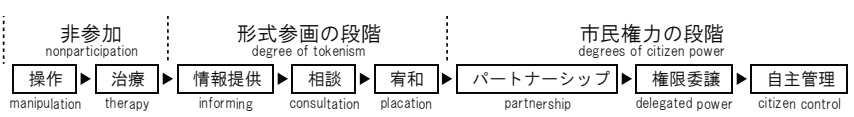

図 1 市民参加の八階梯 
体的な参加、更にはそれを超えた協働を可能にするためには、ユー ザーの意見や要望を設計に取り入れるだけではなく、ユーザー自身 が設計のプロセスを通して設計対象についての理解を深め、納得や 共感を積み重ねることで合意を形成し、更には専門家と肩を並べて 具体的な対象の形を作りだすデザインの活動にも積極的に入り込み、 対象や他の主体との対話を重社、デザインを発展させることが重要 となってくるのである。こうしたプロセスを通して、専門家として の設計者とユーザーとの協働が可能となるのである。注 4$) 3$ 章で述心゙ る本論で対象とするプロジェクトの最も大きな特徴は、一連のデザ インプロセスが、初期のワークショップで子どもたちの描いたスケ ッチや、実際に手を動かして組み上げたプロトタイプ模型から始ま り、最終案に至るまでのデザインに子どもたちの豊かな発想が大き く貢献している点にある。これは決して子どもたちにデザインの専 門的な技能を強いることを意味するのではなく、従来の専門家の役 割であった技術や知識を活かして対象を形作るデザインの概念を拡 張し、非専門家か専門家かに関わらずそれぞれの主体が持つ特有の 観点から対象を見つめ、その新しい姿を描き出す行為として捉え直 すことで理解することが出来る新しいデザインの概念である。

\section{3 世界制作としてのデザイン}

前述のとおり、ユーザーが主体的に設計プロセスに参加するには 設計対象や自らを含むその状況をより良く理解する必要がある。し かしここで言う理解の対象とは、唯一の客観的な事物を指すもので はない。通常我々は、たとえ同じ事物を眺める場合もそこに人それ ぞれの方法で納得したり共感したり愛着をもったりするものである。 つまり我々が認識の対象としているのは、物理的な事物そのもので はなく、そこに我々が描く「世界」(world)なのである。世界はそれ を描く人によって様々である。そして対象物に世界を描くことはそ の対象に一定の枠組や構造を与えることになり、対象物を理解する 手助けとなる。本稿における多様な主体のデザインプロセスへの参 加について議論を行う上で、このような多様な事物の捉え方を許容 する対象の理解や認識のメカニズムは、特に重要になってくる。

このような世界の解釈の多様性・多数性に関しては N.Goodman ${ }^{17)}$ の研究が大変示唆的である。彼は、人は世界を捉えるためのシステ ムであるヴァージョンを設定し、その中で世界を認識し、それぞれ の認識はそれぞれのヴァージョンのもとで正しいと考えた。そして あらゆる世界は唯一の世界に還元でき、そこに唯一の真理があると する唯物論的世界観に対して、数多くの異なった世界を独立した体 系として捉えることの意義と重要性を主張した。

こうした N.Goodman の構成主義的世界観に基づき、D.A.Schön ${ }^{18)}$ はデザイン行為を問題解決や情報処理としてではなく、ある種の「制 作」(making)行為として捉え、その制作の対象となる「デザイン世界」 (design world)なる概念を提唱した。これは設計主体自身がその世界 に入り込み、そこに存在する特定の事物の配列や関係、質との対話 を重衫るデザインの展開の場となるものである。また制作行為は物 理的な事物を形作ることだけではなく、知覚や認識、描写などと連 動するプロセスを通して行われる。このようなデザイン概念の捉え 方によって、なぜ異なる設計主体が同じ事物を異なる方法で捉える のか、それについての議論にどのようにして食い違いが生じるのか、 またその結果異なるデザインのアプローチを採用するのか、などと いったことの説明が可能となるのである。

\section{4 メタファーによる世界}

世界を通した対象の理解を目指寸上で、どのような世界をそこに 描くのかということが理解の質に大きく影響すると考えられるが、 特にユーザーとの十全な協働を目指すならば、非専門家であるユー ザーに専門的な設計言語で構成される世界を描かせてしまうことは 不適切であろう。そこで本プロジェクトでは、メタファーによって 構成される世界を描いていった。 ${ }^{\text {注 }}{ }^{5)}$ Goodman は世界制作の方法と して(a)合成と分解(b)重み付け(c)順序付け(d)削除と補充(e)変形、を 挙げているが、これは(a)ベースとターゲットの要素と構造の対応関 係を捉え、(b)(c)その中から特定の基準となる類似性を発見・抽出し (d)(e)類似しないものは無視、もしくはターゲットへの写像が行われ るというメタファーの認知的メカニズムとも合致するものである。 また、メタファーは「既知の事柄を通して未知の事柄を理解するこ と」として定義され、ユーザーの非専門的な知識体系と専門家の知 識体系との架け橋として機能寸ると考えられるからである。更にメ タファーはその原理上、意味の解釈に至るまでに解釈側の推論のプ ロセスを必ず含むことになる。注6)すなわちメタファーによる世界を ユーザーに提示することは同時にユーザーによる自発的な推論を開 始させることを意味するのである。専門家がユーザーに向けて設計 対象についての一方的な説明を行い、ユーザーがそれを受動的に理 解するという構図の協働ではなく、専門家と共に設計対象について の思考を能動的に展開する、十全な協働を達成するための手がかり がこうしたメタファーの特性に、潜んでいると考えられる。

\section{3. 洛央小学校ブックワールドデザインプロジェクト 3.1 プロジェクトの概要}

本章では分析対象として扱う「洛央小学校ブックワールドデザイ ンプロジェクト」について説明する。

図 2 に示すのは、本プロジェクト以前の京都市洛央小学校の図書 スペース「ブックワールド」である。この小学校は都心型の高密度 な計画がなされた小学校であるため、このブックワールド自体は 2 階（1 階屋上）にある運動場の真下に位置し採光の条件が図書スペ 一スとしてはあまり好ましくないことなど、いつくかの問題を抱え ていた。そこで地域からの寄付金を活用したブックワールドの改修 計画が立ち上がり、2013 年 6 月、その小学校区に属する地域のまち づくり活動に参加していた京都大学の門内研究室が小学校から設計 の依頼を受け、本プロジェクトが始動する運びとなった。門内研究 室では、このプロジェクトを単なる図書スペースの改修計画に留め るのではなく、デザインプロセスを関与する主体の学習と成長のプ ロセスとして捉え、子どもたちを中心とした多様な主体がデザイン プロセスに入り込み、一体となって協働ができるようにプロジェク ト全体のデザインを行った。プロジェクトには、このスペースの主 たるユーザーである約 90 名の小学 6 年生の子どもを中心に、教職 員、設計・施工関係者、地域・行政の関係者らが参加した。協働の 場としては小学校の総合的学習の時間が利用され、ブックワールド のデザインが完成に向けた活動であると同時に、子どもたちの教育 プログラムとしても遂行されることとなった。そして 2014 年 3 月 にブックワールドは竣工を迎えたのであるが、竣工後もブックワー ルドの新しい使い方の発見や空間調整のための設計（照明や音響を など）行うためのワークショップが継続的に行われている。 


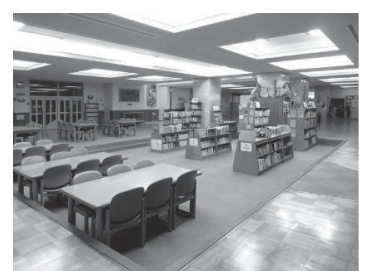

(a) 計画前の写真

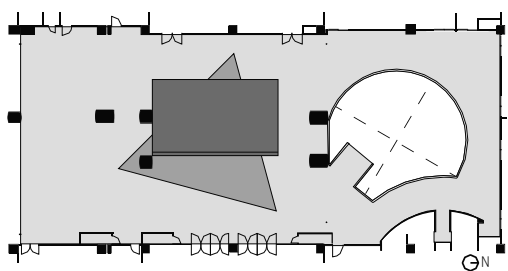

(b) 平面図
図 2 改修前のブックワールド

\section{2 ワークショップの流れ}

本プロジェクトは主に子どもたちとのワークショップで構成さ れる。図 3 には計 4 回の主なワークショップの概要を示しているが、 この他にも教職員らとのワークショップや机・椅子などの寸法を決 定する実物大ワークショップも別の機会に実施している。4 回のワ ークショップは、アイデアの発散段階である第 $1 、 2$ 回のワークショ ップと、収束段階である第 $3 、 4$ 回のワークショップに大きく分けら れる。第 $1 、 2$ 回では子どもたち一人一人にスケッチを書いてもらっ たり、グループに分かれて具体的な形をプロトタイピングしてもら ったりなど、子どもたちに自由な発想を展開してもらい、デザイン の方向性を決める重要なプロセスが展開された。第 3 回は子どもた

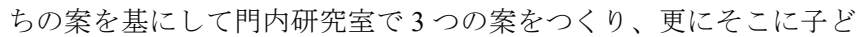
もたちの意見を加え、第 4 回には 1 つの案に統合した。こうした口 ークショップにおいては、一貫して模型や CG によるシミュレーシ ヨン画像・映像を使って子どもたちと情報の交換・共有を行ってお り、対話によるデザインが活発に展開されるように意図している。

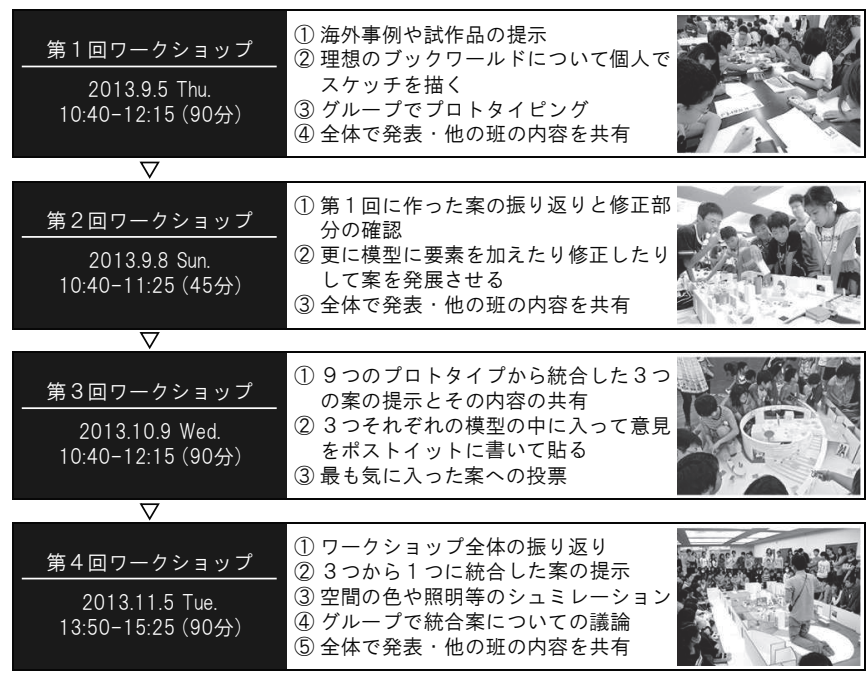

図 3 ワークショップの流れ

\section{3 完成したブックワールド}

以上のようなワークショップを通して新しいブックワールドは 完成に至ったが、ここでは完成したブックワールドについて簡単に 説明を加える。図 4 に竣工したブックワールドの情景写真と平面図 を示寸。第 3 回目のワークショップで作った 3 つの世界がレイヤー システムによって重㸚わされる。これによって、多数決でひとつ の案を選ぶような方法ではなく、今回のプロジェクトの特徴でもあ る多様な主体が関係する協働のプロセスから生まれる多声性を保持 することが可能となる。例えば、ブックワールド中央に位置する円 形に敷かれた青色のカーペットとその上にある台形の可動テーブル

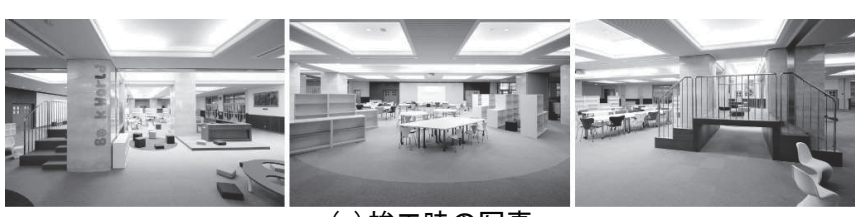

(a) 竣工時の写真

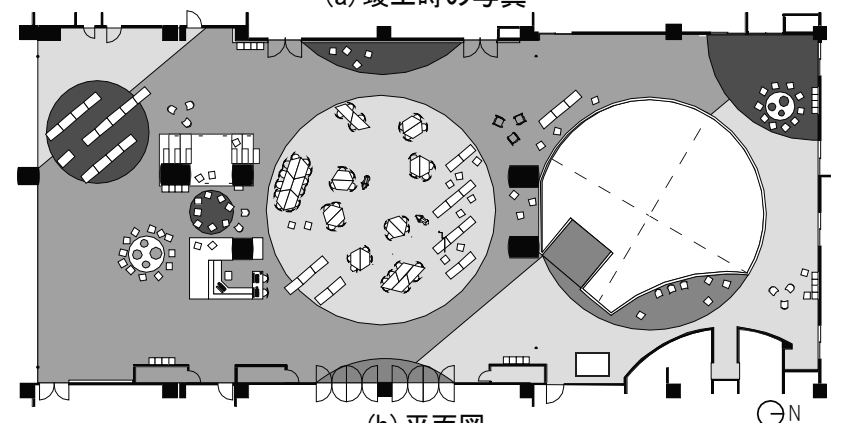

(b) 平面図

図 4 竣エ時のブックワールド

は、青い池にたくさんの舟が浮かんでいるようでもありながら同時 に、青い惑星と宇宙空間を彷得う宇宙船のようでもある、南側の柱 に接するステージ・トンネルは山や洞窟のイメージと共に、素材の 木が住まいの雰囲気を醸し出す、といった具合である。

\section{4. 子供たちが描くブックワールド}

\section{1 生成された言葉とスケッチ}

第 1 回のワークショップでは、はじめにすべての子どもにそれぞ れの考えるブックワールドについてスケッチを描いてもらった。図 5 はその内の一人の子どもが描いたスケッチである。子どもたちの 描いたスケッチには、文字を使った表現が中心的であるものや、絵 による表現が中心的であるもの、またはその両方を使い分けている ものなど、多種多様なタイプのものが含まれている。

スケッチとして子どもによって描かれたアイデアを詳しく見て いくと、そこには図 6〜図 9 に示すように豊富なメタファーが使用 されていることがわかる。これらのメタファーは 5 章で筆者を含む 設計者らで設定した 3 つの世界にも共通するものもあるが、ここで はまず、一連のワークショップを経験する前の子供たちがどのよう なブックワールドを思い描いていたのかを探るべく、子どもたちに よってどのようなメタファーが使用されていたのかを見ていく。

子どもたちのスケッチの中で最も頻繁に使用されていたメタフ アーには図 6〜図 8 に示すような「対象・属性のメタファー」注7)が

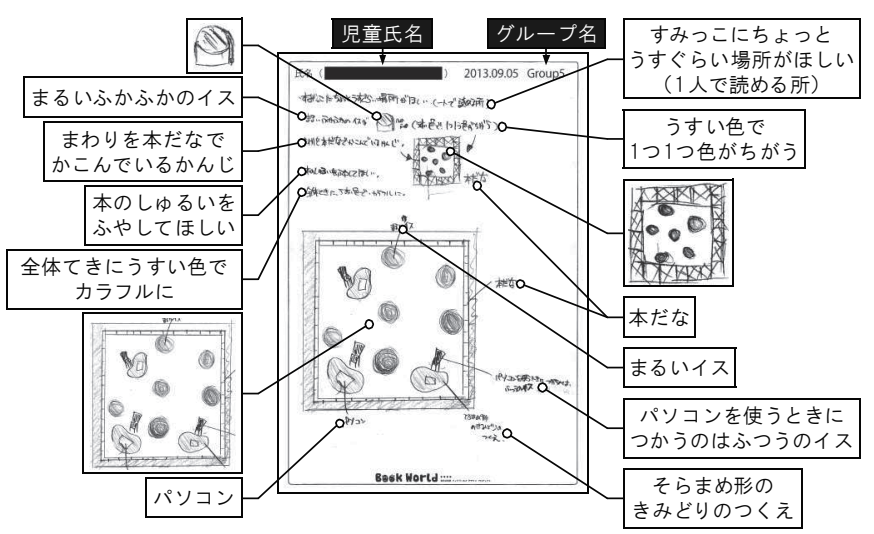

図 5 子供達が描いたスケッチの例 
最も多く含まれていた。この対象・属性のメタファーの中でもそ のベースドメイン (喻える事柄) として多種多様なものが選ばれて いる。図6に示すのは「てんとう虫」の形をした椅子や、「岩」のよ うな形、質感をもった椅子など自然物に関するメタファーである。 また図 7 に示寸のは「ロボット」の形の本棚や「ドーナツ」状の本 棚などの人工物に関するメタファーである。

一般的に図書スペースの設計となると読書行為に関わる機能的 な要件が設計段階に多数現れてくると予想されるが、こうした子ど もたちの既成の概念にとらわれない自由な発想によって生み出され た初源的なイメージは、その後の設計プロセスに大きな影響を与え る可能性を秘めている。事実、最初のスケッチで描かれた「てんと う虫」の椅子は様々な修正や他のアイデアとの統合を繰り返し、最 終案には「てんとう虫テーブル」として実現に至ったのである。

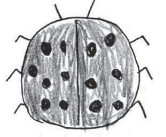

てんとう虫の椅子

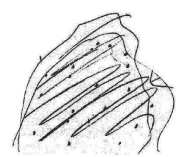

岩の椅子

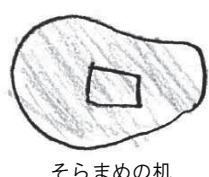

そらまめの机
図 6 メタファーを用いたアイデア（自然物のメタファー）

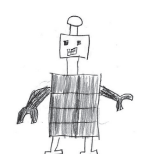

ロボットの本棚

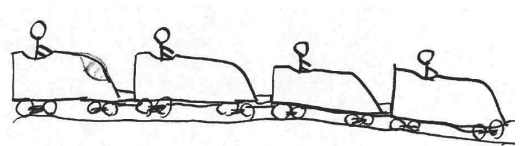

くつのジェットコースター

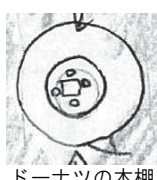

ドーナツの本棚
図 7 メタファーを用いたアイデア（人エ物のメタファー）

また自然物や人工物といった存在物以外に、子どもたちが描いた 対象・属性のメタファーで多かったのは図 8 に示すような、「英語の $\mathrm{B} 」$ の形の机や「ハート」マークの椅子など、言語やマークのメタフ アーであった。一般に我々はこうした言語やマークをそこからなん らかの意味が解採されることを期待して使用する。注8) しかしここで 子どもたちはそうした記号の解釈やその記号が指寸対象ではなく、 記号そのものの持つ属性（形態など）に着目してアイデアを生成し ているのである。注9)こうしたメタファーは、前述した慣れ親しんだ 存在物の属性を写像するメタファー以上に自由な発想によって生み 出されたメタファーであるといえよう。

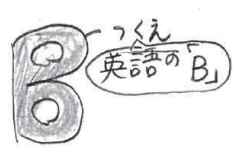

英語のBの机

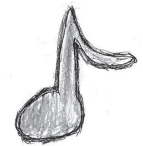

音符の椅子

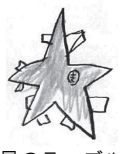

星のテーブル

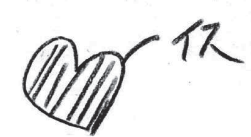

ハートの椅子
図８メタファーを用いたアイデア（言語やマークのメタファー）

更に、対象・属性のメタファーよりも高次の関係・構造のメタフ アーや意味・様相のメタファーも子どもたちによって描かれていた。 図 9(a)に示すのが、「池」「川」「海」といった自然の水の流れの関係 を写像した水槽や「ボール」と「バット」という野球道具としての 対応関係が写像された机とい寸、といった関係・構造のメタファー である。また図 9(b)には、スピーカー等の要素やスクリーンと客席 の関係等が総体としてあらわれる「映画館」のような空間や、多く の本棚や梯子などの要素が林立するような配置がなされることで生

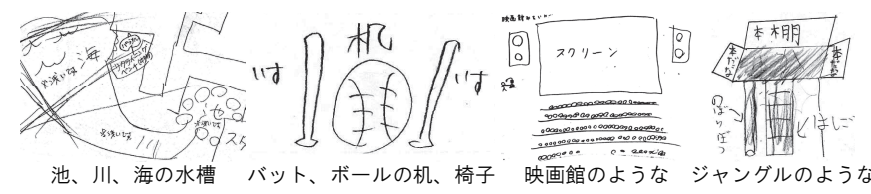

(a) 関係・構造のメタファー

(b) 意味・様相のメタファー

図 9 メタファーを用いたアイデア（高次のメタファー）

まれる「ジャングル」のような空間といった意味・様相のメタファ 一を示している。こういったメタファーのスケッチを見ると、その 数は多くはないものの、決してすべての子どもが形態や色などのイ メージの次元の思考をしているわけではなく、子どもによって様々 な次元の思考が行われていることがわかる。

\section{2 文字で書かれたアイデアに含まれる単語の分類}

次に図 5 で示したスケッチに含まれるアイデアのうち、文字で書 かれたものについてすべて単語に分解し、その分類を行う。更に分

\begin{tabular}{|c|c|c|c|}
\hline & 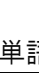 & 分類 & $\begin{aligned} \text { 表 } 1 \text { 分類した単語の例 } \\
\text { 単語の例 }\end{aligned}$ \\
\hline & & 和覚 · 感情 & 見る, 落ち着く, 聞く, 気分, 楽しい, リラックス, さみしい \\
\hline 雷 & & 宁為·動作 & 寝ころぶ, 座る, 降りる，もたれる，もぐる，ごろごろ，寝そべる \\
\hline & & 営為·思考 & 読む, 作る，調べる，落書き, 探す, 飼う, 遊ぶ, 読み聞かせる \\
\hline & & 自然 & 芝生, 川, 水, 洞窟, 山, 海, 惑星, 池, 星, 森, 空, 宇宙, 陸, 夜空, 虹 \\
\hline & & 植物 & 花, 木, キノコ, 植物, コスモス, 葉っぱ, 草, 岩, 丸太, 果物, バラ \\
\hline 秋 & 盗 & 動物 & 魚, てんとう虫, 動物, 象, うさぎ, 爬虫類, 熱帯魚, 猫, 鳥, 犬, 亀 \\
\hline & 筁 & 人 & 低学年, 人, 1 年生, 中学年, 男女, 男, 大人, 足, 先生, 赤ちゃん \\
\hline & & 物質 & ガラス, 石, 木材, 素材, 磁石, レンガ, スポンジ, ゴム, アルミ \\
\hline & & 建築 & 家, 秘密基地, 小屋, かまくら, 東大寺, 体育館, 水族館, 図書館 \\
\hline & & 場所 & 貸出口, 遊び場, 出口, 漫画コーナー, 舞台, サイエンスコーナー \\
\hline & 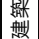 & 室 & 個室, 和室, 野天風呂, 便所, 展示室, 茶の間, 教室, レッスン室 \\
\hline & & 構造物 & 壁, 床, 階段, 屋根, 柱, 螺旋階段, 内壁, かいだん \\
\hline & & 設備・設え & 畳, 扉, 天井, エレベーター, 天空, 通路, 柵, 隠し扉, ライト, 電灯 \\
\hline & & 国·都市 & 橋, 道, トンネル, 土管, 日本, 広場, 京都, 音楽広場, フランス \\
\hline & & 家具 & 家具, ブロック家具 \\
\hline & & 机 & 机, テーブル, 掘りごたつ, つくえ, カウンター, こたつ \\
\hline 事 & & 椅子 & 椅子, イス, 背もたれ, いす, 特別椅子, 座椅子 \\
\hline & 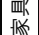 & ソファー & ソファー, ベンチ, 回転ソファー \\
\hline$H$ & & 棚 & 本棚, 棚, 上靴箱, 違い棚 \\
\hline & & 敷物 & クッション, カーペット, マット, 絨毯, 座布団, ウレタンマット \\
\hline & & 寝具 & ハンモック, まくら, ベッド, 布団, 抱き枕 \\
\hline & 礔 & ICT & パソコン, タブレット, タッチパネル, スマホ, ケータイ, iPad \\
\hline & 輁 & 機械 & 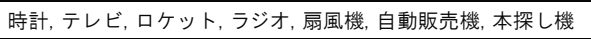 \\
\hline & & 学習 & 本, 地球儀, 勉強マンガ, 赤本, 図鑑, 辞典, 教科書, ランドセル \\
\hline & 岨 & 学校備品 & 水槽, ホワイトボード, スクリーン, ピアノ, 掲示板, シンボル像 \\
\hline & 擐 & 生活 & 梯子, 網, 服, シール, 新聞, 植木鉢, 紙, 靴, 鏡, 脚立, ティッシュ \\
\hline & & 遊戯 & 滑り台, ブランコ, マンガ, 登り棒, 積木, ブロック, トランプ \\
\hline & & 飲食物 & 茶, ごはん, お菓子, 和菓子, 抹茶, 回転寿司, 菓子, マシュマロ \\
\hline & & 季節·行事 & 季節, 年代, 年間行事, 入試, 冬, 現代的, 休み時間, クリスマス \\
\hline & & 文化·芸術 & 音楽, 小説, 絵, 歴史, 物語, 風景, 電子映像, 曲, 絵本, 映画 \\
\hline & & 形状 & 形, 丸い, 立方体, 三角, カタチ, 螺旋, 平べったい, 四角, カーブ \\
\hline & & 寸法 & 低い, 大きい, 小さい, 広い, 長い, 大きな, 高い, 薄い, 浅い, 幅 \\
\hline & 跑 & 色彩 & 色, カラフル, 明るい, 透明だ, 緑, 藍色, 薄暗い, 黄緑, ピンク, 紫 \\
\hline & 烈 & 模様 & 柄, 水玉, 花柄, 柄入り, 模様, 飾り，にこちゃん模様 \\
\hline & & 触覚 & ふかふか, 柔らかい, ふわふわ, 低反発, やわらかだ, つるつる \\
\hline 畟 & & 聴·嗅·味覚 & 静かだ, 香り, 美味しい, 匂い, 騒がしい, にぎやかだ, うるさい \\
\hline 婓 & & 数量 & たくさん, ちょっと, 5 人, 皆, 量, 両方, 半分, 多い, 全部, 少ない \\
\hline & & 種類 & いろんな, 普通, 珍しい, 色々, 種類, メリハリ, ジャンル \\
\hline & & 立置·方向 & 中, 上, 周り, 下, 真ん中, 間, 横, 両端, 内, 中心, 向き, 隅っこ, 角 \\
\hline & & 状態 & 自由に, 立てる, 埋込み式, 覆う, 敷く, 備え付け, 秘密だ, 固定 \\
\hline & & 機能 & 入れる, 変えられる, 動かせる, 回る, 片付けられる, 描ける \\
\hline & & 意味 & シンプルだ, 雾囲気, かわいい, 華やかだ, 安全だ, どくどくしい \\
\hline
\end{tabular}


類した単語の集計を行うことで、子どもたちのアイデアにはどうい った種類の概念が含まれているのかということや、ひいては子ども たちの思考や発想の傾向を読み取っていく。

表 1 には今回行った分類の一部を示しているが、図書スペースと しての枠組みを超えた多様な概念が多く生成されていることがわか る。ただしここには 5.4 節で行う模型上に貼られたポストイットに 含まれる単語も含めている。分類を決める上で、はじめにブックワ ールドを利用する人たちの知覚や行為、思考・活動などの動詞的単 語としての「行動」自然物と人工物に大別される名詞的単語として の「存在物」、主に存在物を修飾し、その属性や機能、様相を表寸形 容詞・副詞的単語としての「特徵」に分け、更にそれぞれの分類の 中に細分類を設定している。細分類を行う際には、分類ごとの単語 数に極端な差が極力生じないように配慮した。また、各アイデアを 表現する文の中でほぼそのアイデアの内容に影響を与えないような ものと判断できる単語は分類から省略した。注 ${ }^{10)}$ 以上のような手順 で単語の分類を行った結果、第 1 回ワークショップの参加者 89 名 のスケッチから計 1049 個の単語が得られた。

図 10 はす心゙ての単語に対する、前述した分類毎の単語の数の割 合をそれぞれの分類について示したものである。ただしここでは分 類のうち、名詞的単語である「存在物」に含まれる分類を扱うこと にする。前節では「自然物」に関するメタファーについて述べたが、 ここでも「山」や「川」といった自然に関する単語が多くなってお り、図書スペースとしての典型的な像から離れ自由な思考が行われ ていることがわかる。しかしそれ以上に「机」や「椅子」「棚（ここ に含まれる単語の殆どは「本棚」)」といった、図書スペースには不 可欠な要素も突出して多く現れており、自由な発想を展開する一方 で従来の一般的な図書スペースのイメージも子じもたちの思考に根 強く存在することが予想される。

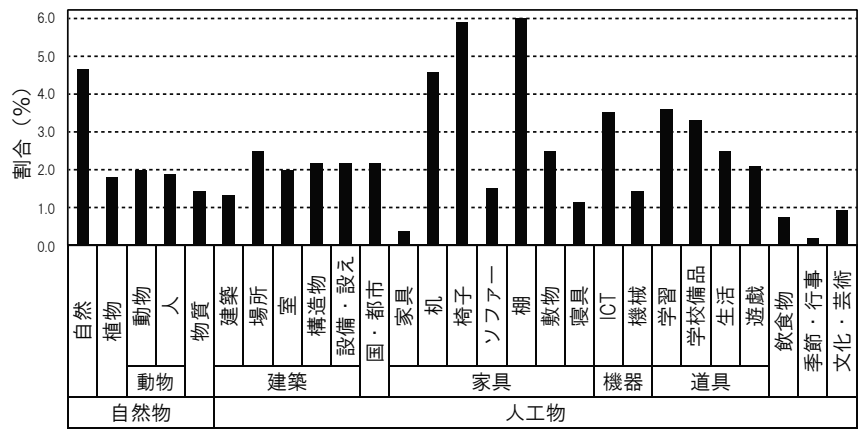

図 10 スケッチの文字による記述に含まれる単語の分類（一部）

\section{3 各班で統合されたブックワールド}

第 1 回のワークショップでは子どもそれぞれに自由にスケッチを 描いてもらった後に、9つの班に分かれてそれぞれ一つの模型とし て紙や粘土など様々な素材を使ってデザインのプロトタイピングを 行った。そしてワークショップ後にそのプロトタイプを、筆者らを 含むワークショップの運営側で、各要素を適切なスケールに落とし こんだり、ある程度現実的に利用可能な形態に修正したりして子ど もたちの案を整理した。更に第 2 回のワークショップではその整理 したプロトタイプ模型に子どもたちが新たな要素の追加や配置の変 更などの修正を加えた。図 11 に示寸のはそうしてつくられた 9 個
の案の一部の例を示している。また各ワークショップの最後にはそ れぞれの班が自分たちの案を発表し合い、その時点で他の班がどの ような案を作っているのかを確認しあい、情報を共有した。

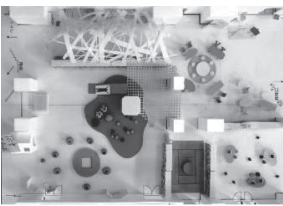

（a） 2 班の模型

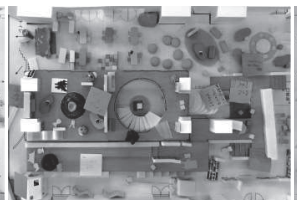

(b) 3 班の模型

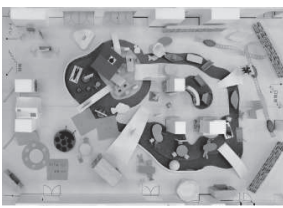

（c）９班の模型

\section{図 11 プロトタイプの例}

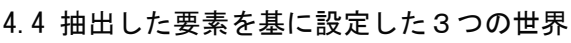

その後、これまでのワークショップの中で子どもたちが描いたス ケッチや、各班で作られ、修正が重ねられた模型を基にして、第 3 回のワークショップに向けて 3 つの案の作成を運営者側で行った。 ここではまず(1)4.1 節で示した子どもらが描いたスケッチと、各班 に分かれて制作したプロトタイプ模型に含まれる要素を抽出し、そ の内、絵や模型で表現されたものはそれが何を表しているのかをワ ークショップ時に各班を担当したファシリテーターの話を参考にし ながら運営側で解釈し、言葉に置き換えた。次に(2)選び出した要素 から似たものを選びとってグルーピングを行い、(3)試行錯誤を重ね、 最も上手くまとまる 3 つのグルーピングができたところでそれぞれ のグループの特徴を示す、図 12 に示すような「自然・原っぱ」「未

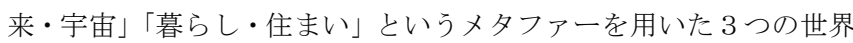
を設定した。注 11) そして運営の $2 ， 3$ 人のメンバーで構成されるチ 一ムを 3 つ作り、それぞれ設定した世界をテーマとした 3 つ案を 制作し、それぞれの案の中にこれまでに子どもたちによって出され たアイデアをできるだけ多く詰め込めるように設計を行った。注 12 ) 第 3 回のワークショップ時には以上の手順を子どもたちに説明し、 3つの世界について紹介をした上で、各案に潜んでいる子どもたち のアイデアに触れながら、案全体の説明を代表者が行った。
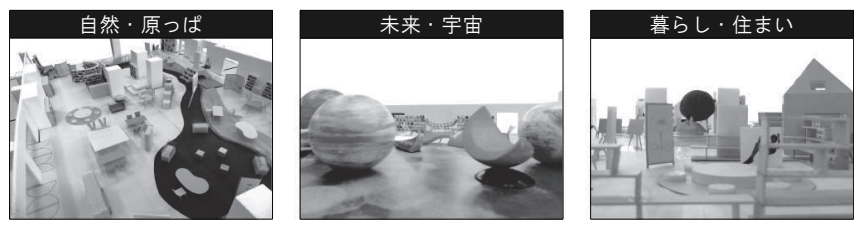

図 12 設定した3つの世界

5. 3つの世界を通した合意形成のプロセス

5.13 つの世界に基づくブックワールド

4.4 節で示したそれぞれの世界に基づいて、3つの案を作成した。 図 13 にはそれぞれの案の平面図と模型写真を示している。

(a)に示すのは「自然・原っぱ」案であり、池のように自由曲線で 囲まれ少しくぼんだ位置に水色のカーペットがひかれる、原っぱの ような緑のカーペットがある、てんとう虫の形をしたテーブルが配 置される、などといった「自然・原っぱ」の世界が表現されている。

(b)に示すのは「未来・宇宙」案であるが、惑星のような円や未来 を表現するダイアナログな直線等で構成される平面図や、宇宙船の ような立体構成、宇宙に関連する機能として入れたプラネタリウム などに「未来・宇宙」の世界が表現されている。更に(c)に示すのは 

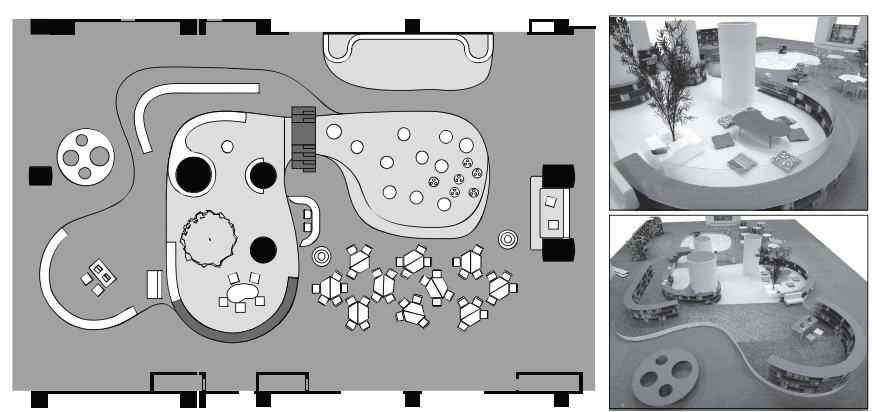

(a)「自然・原っぱ」案
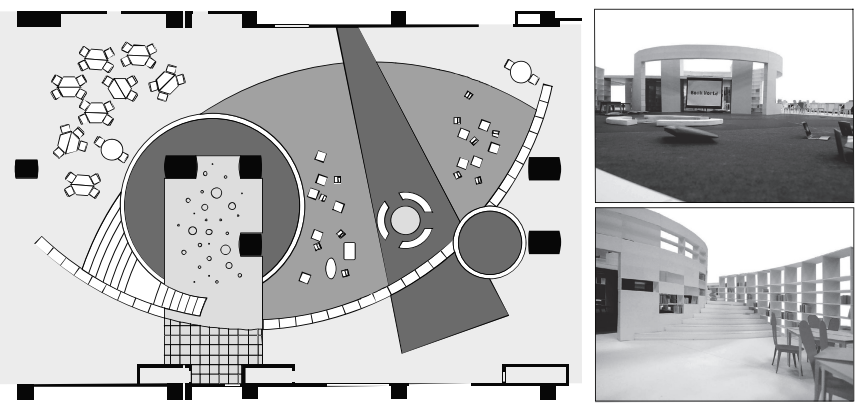

(b)「未来·宇宙」案

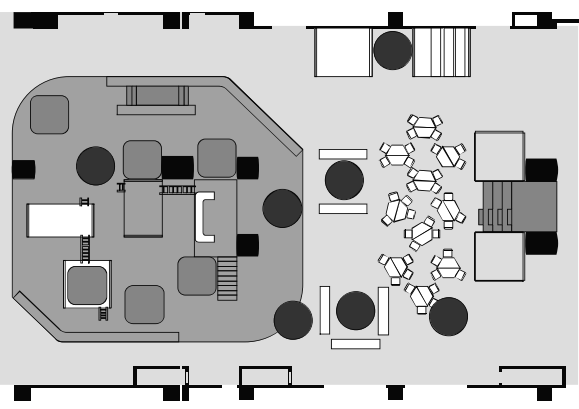

(c)「暮らし・住まい」案

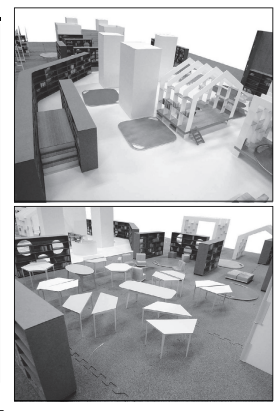

図 13 3つの世界をもとにした設計案注 ${ }^{13)}$

「暮らし・住まい」案であるが、小さな家の形をしたデンのような 空間や、自由に持ち運びが可能な座布団のようなラグ、可動本棚に よって囲まれるこぢんまりとしたスケールの落ち着ける空間などに 「暮らし・住まい」世界が表現されている。

以上のような 3 つの案を準備し、それぞれの模型を $1 / 10$ の縮 尺で作成した。これらの模型は約 $2 \mathrm{~m} \times 3 \mathrm{~m}$ の大きさで、ワークシ ヨップの際には子どもたちが模型の中に実際に入ることが可能なほ ぞの巨大な模型である。

\section{2 各案についての評価と提案}

第 3 回のワークショップでは図 14 に示寸通り、前節で示した 3 つの案の巨大模型を用いて、子どもたちが実際にその中に入って意 見をポストイットに書き、直接模型の気になった箇所に張っていっ てもらった。ワークショップの終了時には「自然・原っぱ」の案に は計 489 枚、「未来・宇宙」案には計 361 枚、「暮らし・住まい」案 には計 335 枚ものポストイットがはられていた。貼られたポストイ
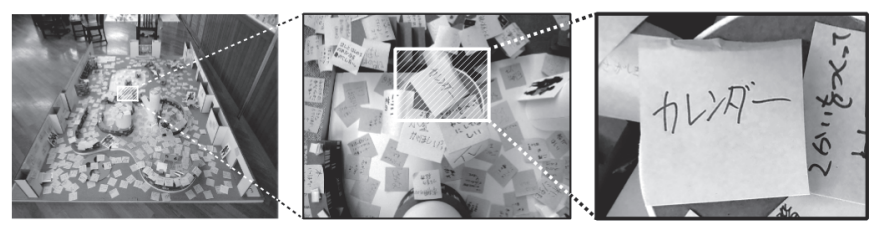

図 14 模型にはられたポストイット
ットの多くは「ホワイトボードに自由に描けるようにしたい」や「秘 密基地のような場所がほしい」のような新しい「提案型」のもので あったが、「(この) 川に囲まれたこもれる部分がいい」といった高 い評価を下しているもの、「コーヒーメーカー皆で食事できるカフェ みたいな䨌囲気」といった状況の記述を行っているもの、「階段から 落ちる人がいるかも…といった低い評価を下しているもの等の「評 価型」のものも存在した。ここですべてのポストイットを評価型と 提案型に分類し、それぞれ 5.3 節と 5.4 節で詳細に分析していく。

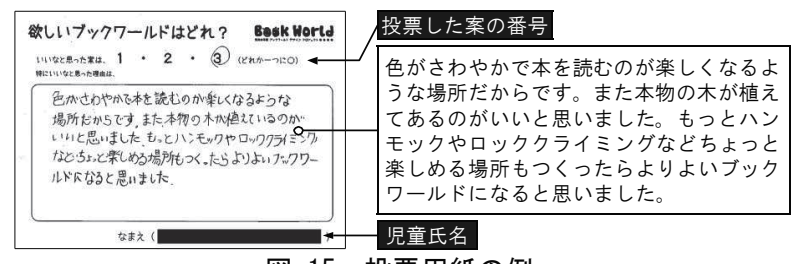

図 15 投票用紙の例

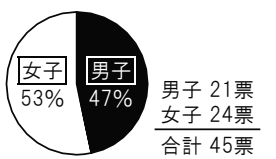

(a)「自然・原っぱ」案

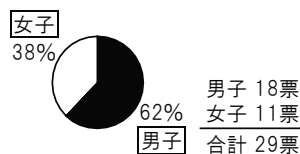

(b)「未来・宇宙」案

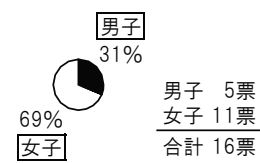
(c)「暮らし・住まい」案

更に案に対する子どもたちの評価に関して、第 3 回のワークショ ップの最後には図 15 に示すような投票用紙を参加した子ども全員 に配布し、それぞれの気に入った案の番号とその案を選んだ理由に ついて記入してもらった。

図 16 には上記の投票の結果を示している。「自然・原っぱ」案の 得票が最も多く、「未来・宇宙」案「暮らし・住まい」案がその後に 続く形となり、模型に貼られたポストイットの枚数の順位と同じと なった。男女比は「自然・原っぱ」案は投票した子どもの内女子の ほうが多いことも考慮するとほぼ同じ割合であった。一方で「未来・ 宇宙」案については男子が、「暮らし・住まい」案については女子が 多くなっており、性別による好みとなる世界の差異が垣間見える。

\section{3 制作した世界についての発見}

本節では、3つの世界を通して子どもたちがそれぞれの設計対象 をどのように捉え、そこにいかなる価值や意味を発見したのかを探 っていく。注 ${ }^{14)}$ 前節でも述べたように、まずは模型に貼られたポス トイットの内、評価型の意見が書かれたものをみていく。

ここでまずすべての評価型の意見を「高評価」「記述」「低評価」 の 3 つに分類した。図 17 には各案についてのそれぞれの分類の枚 数と貼られたポストイットに書かれた意見の例とそのポストイット が貼られたおおよその位置を示している。これを見ると、「自然・原 っぱ」案の中央の「池」は「川」と読み替えられたり、「未来・宇宙」 案の「宇宙船」のイメージ全体像を「ロケット」と読み替えたり、 類似の概念ではあるが、それぞれの世界の中で設計言語を自身で調 整しながらそれらを駆使し、対象の評価を行っていることがわかる。

次に投票用紙に記入された投票の理由についてみていく。図 18 に はその例を示している。これを見ると、子どもがそれぞれの案を評 価する上で、「自然・原っぱ」案であれば「川」「野原」「動物」など、

「未来・宇宙」案であれば「宇宙船」「未来」「タイムスリップ」な じ、「暮らし・住まい」案では「家」「ッリーハウス」「秘密基地」な 


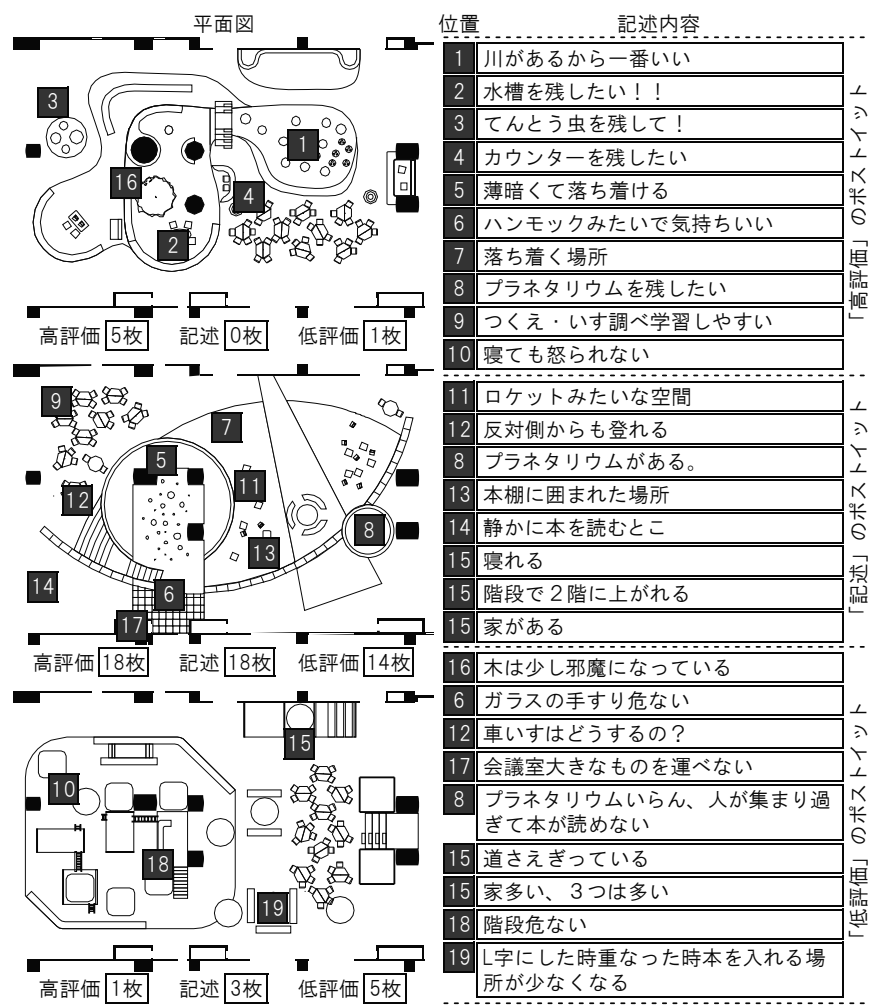

図 17 模型に貼られたポストイット

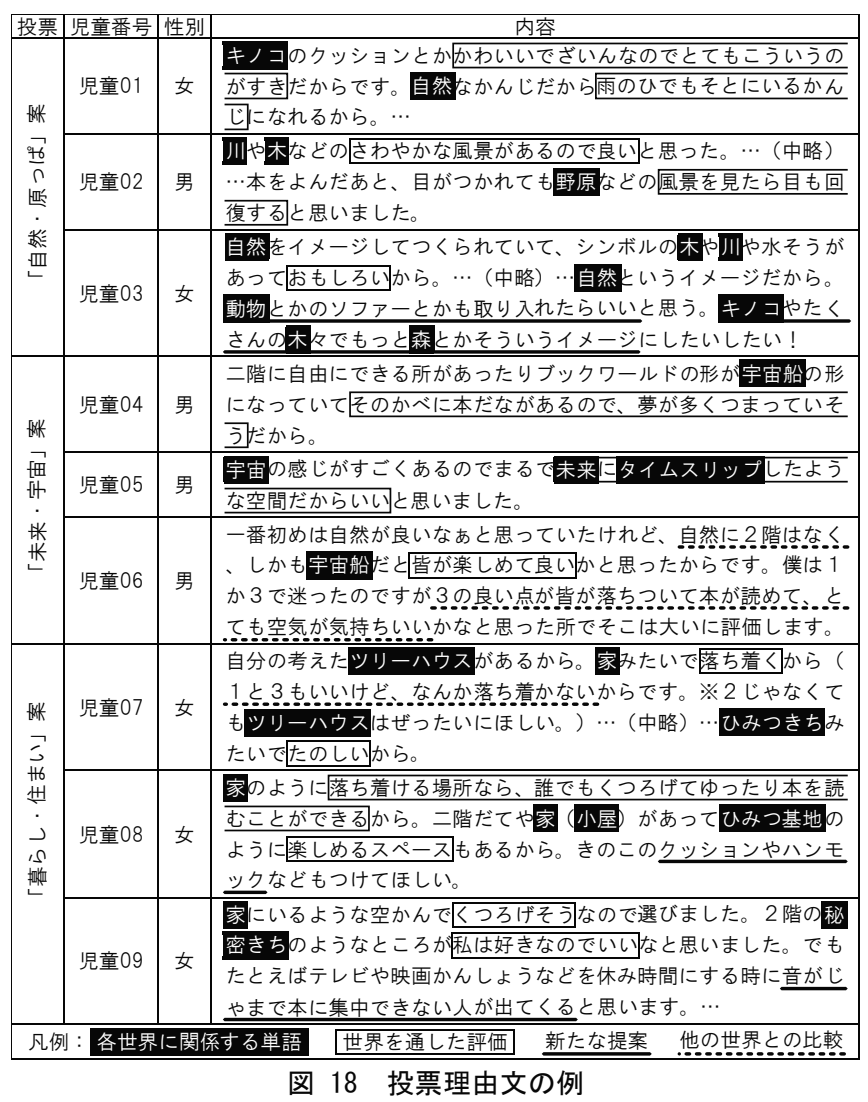

ど、それぞれの世界の構成要素となるような概念が頻出しているこ とがわかる(黒い背景で示した部分)。またそうした概念を通して川 や木の「さわやかな風景」の良さや、家のような「落ち着ける場所」 では「ゆったり本を読むことができる」ことなどを認識しているこ とがわかる(四角で囲った部分)。また、ここでは投票の理由を記入
することだけが求められていたにも関わらず、そうした認識を通し て自ら新たな提案も行われている（実線のアンダーラインで示した 部分)。更に特筆すべきは、自分が投票した案の世界だけではなく、 他の案もその世界を認識しながら比較・検討を重ね案の評価を行っ ているという点である（点線のアンダーラインで示した部分）。

図 19 には子どもが記入した投票の理由文の中から、それぞれの 案の世界に関係しうる単語（図18 の凡例の中で「各世界に関係する 単語」として示しているもの）を選び出し、集計したものである。 これをみると、描く世界によってその中で子どもたちが展開する概 念領域の広がりが様々であることがわかる。この結果はメタファー のベースドメインの概念に対する子どもたちの理解度に依存するも のであることが予想される。従って今回のように専門家側から設定 する世界を提供する際には、その世界の中で子どもたちにより広い 範囲に思考を広げることを期待するのであれば、予めユーザーの希 望・意見・提案などを十分に把握し、選択するメタファーの質やメ タファーに対する子どもの親近具合を予測する必要があるだろう。

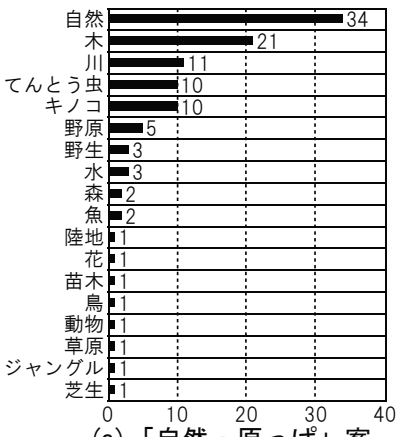

(a)「自然・原っぱ」案
図 193 案の評価を通して生成された単語

\section{4 次なる世界に向けた創造}

最後に各案において、3つの世界にもとづいて更なる案の発展の ために子どもたちが何を創造したのかをみていく。5.3 節でも述心゙ たようにここでは各案に対する評価と並行して模型に貼られたポス トイットの内、提案型の意見が書かれたものを扱う。

はじめに、 4.2 節と同様に、ポストイットのアイデアとして記入さ れた文を単語に分解していき、その分類を行った。分類した単語数 は「自然・原っぱ」案が 780 個、「未来・宇宙」案が 575 個、「暮ら し・住まい」案が 577 個となった。図 20 には 3 つの案それぞれにつ いての各分類の単語の出現頻度割合を示している。

3 案を総じて見てみると、4.2 節でみた子どもたちがプロジェク 卜初期に書いたスケッチに含まれる単語の頻度分布とは大きく傾向 が異なることがわかる。すなわち、スケッチの段階では、一般的な 図書スペースに付随する「机」や「椅子」、「棚」といった要素が多 くなっているのに対して、模型に貼ったポストイットに含まれる単 語に関しては、案によりばらつきはあるものの上記の単語は決して 多く出現するわけではなかった。その分各案の世界に基づいた単語 が多く出現しており、一般的な図書スペースのイメージから発想が 大きく広がっていることが伺える。

ここから具体的に各案でどのような単語が多く出現し、それぞれ の設定した世界がどのように子どもたちの発想を誘導していったの かを詳しく見ていく。まず、「自然・原っぱ」案では「自然」や「植 
物」、動物」といった自然物に関するものが多くなっており、設定 した「自然・原っぱ」の世界の中で子供達の発想が大きく広がって いることがわかる。また「マシュマロ」の「椅子」や「中華まん」 の「椅子」といった飲食物のメタファーが椅子のアイデアとして頻 繁に出されていたために、「椅子」と「飲食物」の単語が多く出現す る結果となった。

次に「未来・宇宙」案についてみると、「ICT」や「機械」のアイ デアが多く「自然・原っぱ」案と同様に設定した世界が生成される 単語の傾向に影響を与えていることが見て取れる。またこの案では 比較的大きな中 2 階部分を設えており、その要素に対する賛否が多 く、そのため「2 階」などの単語を中心とした「場所」の単語が他 の案と比べると多くなっていた。

最後に「暮らし・住まい」案について見てみると、「建築」の分類 の中でも「構造物」の出現頻度が大きく出ている。この「構造物」 の分類に含まれるのは「壁」や「階段」、屋根」といった建築物の 主要要素である。模型の中に家型のデンのような要素もあったこと から、「住まい・暮らし」から「家」などの建築のイメージが連想さ れた結果であると予想される。また、「壁掛け TV」や「紙などを貼 るための壁」など、自宅における日常生活を支えるようなアイデア が多かったことも、この案に設定した世界の影響が大きかったため であると考えられる。

以上のように設定した世界が子どもの発想の広がりに影響を与 えることを確認できたが、ここで重要なのはこれらの発想が決して 世界の設定を行った運営側がそれをコントロールすることを意図す るものでもなければ、コントロールの範囲に収まるものでもないと いうことである。設定した世界は子どもたちの発想の起点となるの であるが、その後の発想の展開は子どもたちに委ねられるのであり、 その事態こそが子どもたちの主体的な参加を導くための手がかりと なるのである。そしてここに、解釈者に必然的に推論を要請するメ タファーによって世界を設定することの意義があると考えられる。

\section{6. 結論と今後の課題}

本論ではユーザーとの協衝による設計プロセスにおける、メタフ アーを使った設計手法の可能性を探るべく、京都市洛央小学校ブッ クワールドプロジェクトの事例を取り上げ、小学校の子どもたちを 主体とした協働のプロセスにおいて、メタファーがいかに設計主体 の思考の広がりと参加への主体性形成に影響を与えるのかについて 分析を行った。具体的には、設計プロセスにおける案の統合過程で、 設計の初期段階に子どもたちが出したアイデアを基にして 3 つのメ タファーによる世界を設定し、それぞれの世界に基づく設計案を作 成して、子どもたちが 3 つの世界に入りこんで修正と新たな創造の 繰り返しによる各設計案の発展プロセスを詳しく見てきた。その結 果、次のような $2 つ の$ 事柄を明らかにすることができた。

(1)設計対象の属性や機能などを見つけ出す「発見」のプロセスや、 新たなアイデアを紡ぎだす「創造」のプロセスにおいて、子ども たちの発想が設定した世界を起点として広がり、そこに新たな要 素を加えたり修正を重ねたりすることでその世界を豊かにするよ うにして設計対象に関する発見と創造を繰り返す様子を、子ども たちの描いたスケッチや模型に貼られたたくさんのアイデアから 確認することができた。

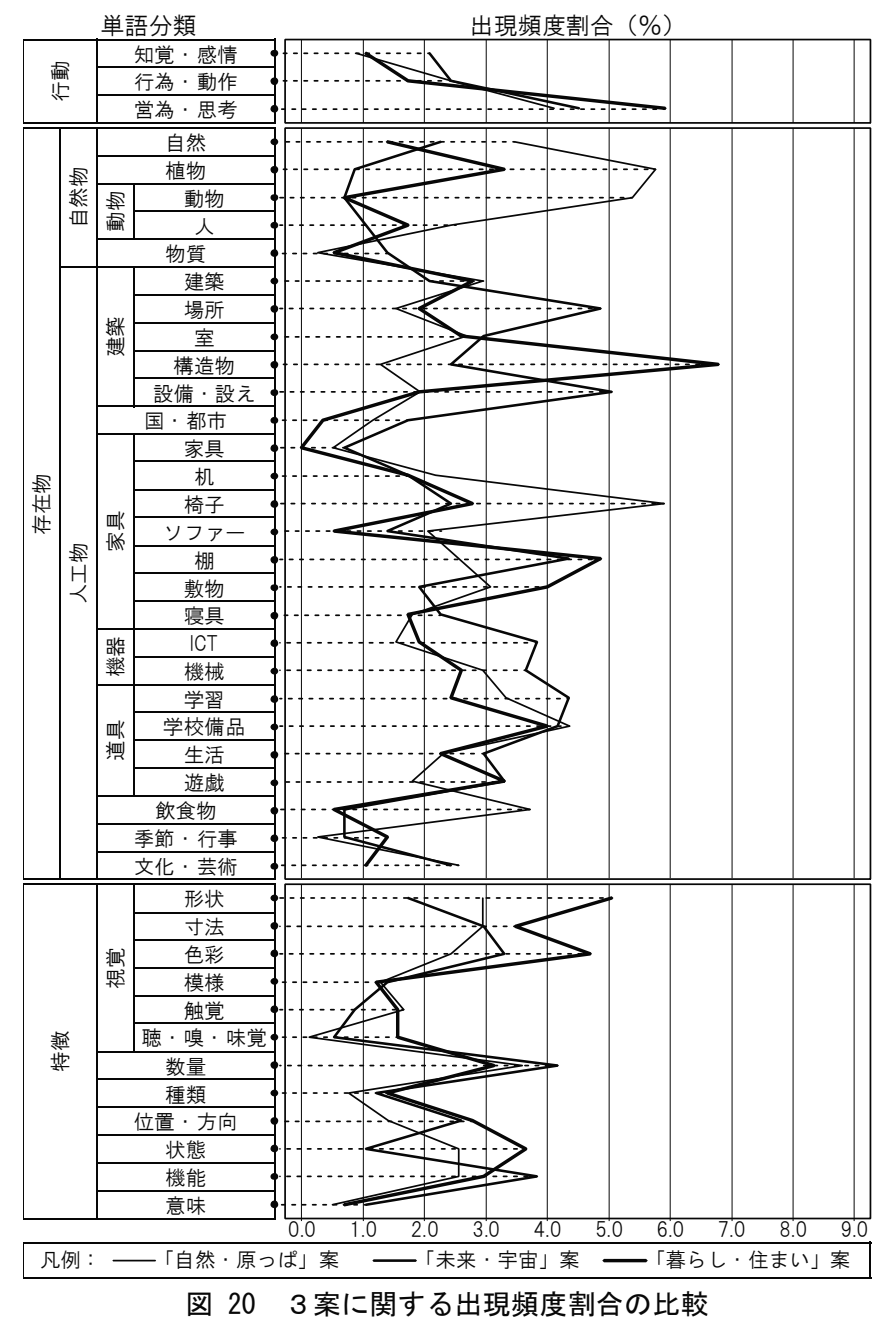

(2)世界を設定することが子どもたちの発想を広げる力を持つだけで なく、それがメタファーによる世界であることによって、子ども たちが自発的に世界を拡張することになり、結果として主体的な 参加を可能にすることができる、というユーザーを主体とした協 働の設計プロセスに向けたメタファーの可能性を示した。

今回対象としたのは主に小学 6 年生の子どもたちとの協働のプ ロセスであったが、その特徴としては 4.1 節で見たスケッチにいく つか異なる次元のメタファーが含まれていたように、彼らが生成す るアイデアには、空間のイメージやメタファー等の詩的、芸術的な ものから、人間の生物としての行動・動作に関わるもの、そして本 を読む、勉強をする等の論理・思考に関わる多様な次元のものが含 まれていた。こうした結果からも子どもとの協㗢によるデザインを 試みる場合には、子どもの成長の段階を考慮し、ワークショップの 運営に工夫を加える事が重要になる。例えば、5.3 節で述べたように、 メタファーが既知の事柄を基にした推論の形式である以上、設定す るメタファーの選択においてはユーザーの知識体系に配慮しなけれ ばならない。より一般的な方法論の確立を目指す上での課題は、更 なる実践的事例を通した研究の蓄積を図ることである。

注

注1）メタファーにおいて喻える事柄をベースドメイン、喻えられる事柄を ターゲットドメイン呼び、両者の類似性に基づいてベースからターゲ 
ットへ特定の要素が写像される。このメカニズムにメタファーが対象 に関する新たな発見や創造を行う創造的側面が含まれる。

注2） 本プロジェクトは小学校の子どもたちを中心としたユーザーが設計主 体として建築の設計プロセスに入り込む点に大きな特徵があるが、筆 者らは建築設計とプロジェクト全体のデザイナーの専門家であると同 時にそのプロセスの記述・分析を行う研究者としてもプロジェクトに 参加し、アクションリサーチとして一連の活動を遂行している。

注3）子どもを対象とする建築や都市のデザインの事例は近年増加しており、 例えばドイツの統合学校における子どもと専門家が 1/10 の巨大模型を 使って議論を行うワークショッブ等がある。

注4）近藤らは S.R.アーンスタインが議論するような「参加」の概念とその 発展形である「協働」の概念を区別している。本論も「協働」を目指す ものであるが、本論で得る知見はあらゆる参加の次元でも適用可能な ものであると考えられるので、特にこのふたつの概念の明確な区別は 行わないこととする。

注5）世界は主体(world maker)自身によって描かれるのであり、どこからか付 与されるようなものではないとされる。ここで筆者らが子どもに提供 したのはあくまで世界を描くきっかけに過ぎず、それを起点にして子 どもたちはそれぞれの世界制作を展開するのである。

注6) G.A.ミラー ${ }^{19)}$ は、類似性に基づくメタファーの論理的定式化を通して 次の 3 つのメタファーを区別している。（ただし、 $x, y$ を変数、 $F, G$ を関数、SIM を類似的関係を表す記号とし、ヨをある変数、関数が存 在することを表す記号とする。)

\section{M1. $B E(x, y) \rightarrow\left({ }^{\exists} F\right)\left({ }^{\exists} G\right)\{\operatorname{SIM}[F(x), G(y)]\}$ \\ M2. $G(x) \rightarrow\left({ }^{\exists} F\right)\left({ }^{\exists} y\right)\{\operatorname{SIM}[F(x), G(y)]\}$ \\ M3. $G(y) \rightarrow\left({ }^{\exists} F\right)\left({ }^{\exists} x\right)\{\operatorname{SIM}[F(x), G(y)]\}$}

このとき、M1、M2、M3 は、それぞれ「名辞的」、「述語的」、「文的」 メタファーと呼ばれ、M1 では比例関係に基づいて隠されている項を、 M2では隠されている述語を、M3 は項と述語の組からなる命題をまる ごと推測しなければならない。門内 ${ }^{20)}$ はこのモデルを用いて、建築に おけるメタファー分析を行っている。

注7）筆者らはこれまでの研究を通して、ベースドメイン (喻える事柄) から ターゲットドメイン (喻えられる事柄) 一写像される内容が(1)「対象・ 属性」であるか(2)「関係・構造」であるか、もしくは(3)「意味・様相」 であるかによってメタファーを 3 つに分類している。詳細については 参考文献 2) を参照

注8）ここで言う言語やマークは哲学者 C.S. パース ${ }^{21)}$ の記号論における象徴 記号(symbol)であり、これは記号と対象が法則や規範、習慣によって結 び付けられるものである。

注9）パースはあらゆる現象を、何かそれ自体であって他のものと関係を持 たないようなものの在り方である「一次性」、何か他のものと関係して いるが、いかなる第三のものをも含まないようなものの在り方である 「二次性」、第二のものと第三のものを互いに関連づけるようなものの 在り方である「三次性」という普遍的なカテゴリーを提唱し、二は一を 含み、三は二と一を含むとしたが、記号と対象の関係を媒介する第三 項が存在する象徴記号における記号それ自体は三次性に含まれる一次 性であり、パースはこうした関係を「退化」(degeneration)と呼んだ。

注10）具体的には「もの」「こと」「とき」「ところ」などといった、アイデア の文の語尾に付くような単語は、今回は分類から除いている。

注11）スケッチや模型から要素を抽出する際には以下に示すようポストイッ トを用い、一面にそれらを張り出して様々なグルーピングを試みた。

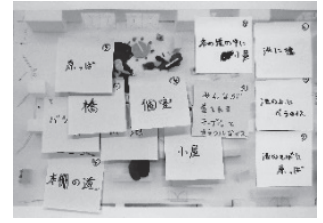

プロトタイプ模型から要素を抽出

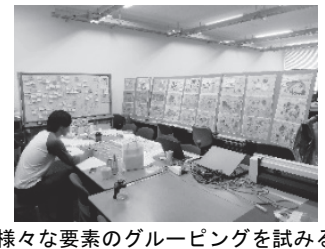

注12）筆者らが設定した世界は、子どもたちが出したアイデアを基にしたも のであるが、これらの世界は子じもらの意見やアイデアから演繹的に 生成されるものではなく、仮説的かつ発見的に紡ぎ出した世界である。 従って同じ子どもたちのアイデアから全く異なる別の世界を描き出す

\begin{tabular}{|c|c|c|c|}
\hline & 自然・原っぱ & 未来·宇宙 & 暮らし \\
\hline スケッチ & 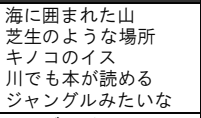 & $\begin{array}{l}P C \text { (検索したり) } \\
\text { 曲面に本 } \\
\text { ゆかを透明にする } \\
\text { ガラスとアルミ素材 } \\
\text { ロボットの本だな }\end{array}$ & $\begin{array}{l}\text { ねころんで読める場所 } \\
\text { ごろごろスペース } \\
\text { ふかふかのソファー } \\
\text { 和室 } \\
\text { 畳 }\end{array}$ \\
\hline 模型 & $\begin{array}{l}\text { リンゴの形のスツール } \\
\text { 芝生のゾーン } \\
\text { ツリーハウス } \\
\text { てんとう虫のソファー } \\
\text { 蓮の葉の形のスッール }\end{array}$ & $\begin{array}{l}\text { 三日月のハンモック } \\
\text { 吾ラネタリウム } \\
\text { 惑星のオブジェ } \\
\text { 宇宙のカーペット } \\
\text { 宇宙船のハンモック }\end{array}$ & $\begin{array}{l}\text { 円形の小屋 } \\
\text { ロフト } \\
\text { バランスボール } \\
\text { 丸い和室スペース } \\
\text { 三角屋根の小さな家 } \\
\end{array}$ \\
\hline
\end{tabular}

ことも十分に可能であるだろう。今回設定した世界を導く際にその根 拠とした子どもたちの具体的な意見やアイデアの要素の一部を示す。 ただし、ここでは絵で書かれたスケッチや模型の要素は筆者らが解釈 した言葉で表記している。

注13）一連のワークショップでは子どもたちに家具類の模型キットを配布し た。一般的な長方形、円形等の机もその中に含まれていたが、ワークシ ヨップ以前からこのスペースで様々な活動を行うことを狙いとして、 多様な組合せが可能な台形の机も含めていた。それらは子どもたちに も人気で、各班のプロトタイプ模型でも頻繁に使用されていたことか ら最終案にもこの机を用いることにした。

注14） 5.3 節と 5.4 節ではそれぞれ「発見」と「創造」として子どもたちの活 動を分けて扱っているが、どちらもデザイン行為の一部であるとして 捉えている。池辺陽 ${ }^{22)}$ は本来のデザインは直接ものをつくることにつ ながるのではなく、存在するものに対して新たな生命を発見すること にあると考え、「発見としてのデザイン」について述べている。

\section{参考文献}

1）門内輝行：設計方法論の展開，建築雑誌 - 研究年報，104 巻 1290 号, pp.30-31, 1989.9

2）酒谷粋将，岡本賢吾，門内輝行：建築作品にみるメタファーの類型化と 構造分析一建築設計におけるメタファーの解読と生成その 1 , 日本建築 学会計画系論文集, Vol. 78, No.685, pp.527-536, 2013.3

3）酒谷粋将, 岡本賢吾, 門内輝行：設計プロセスにみるメタファーの構造 と機能一建築設計におけるメタファーの解読と生成その 2 , 日本建築学 会計画系論文集, Vol.79, No.685, pp.2153-2163, 2014.10

4）酒谷粋将, 門内輝行：メタファーによる思考における発散と収束のプロ セスーデザイン思考のプロセスにみるメタファーの機能その 1 , 日本建 築学会計画系論文集, Vol.80, No.707,pp.53-63, 2015.1

5) Sanoff, H. : Community participation methods in design and planning, John Wiley, 2000

6）ハルプリン,R., バーンズ,J.（訳 杉江伸太郎，杉江邦江）：集団による 創造性の開発一テイキング・パート，牧野出版, 1989

7）近藤早映, 瀬田史彦：公共施設整備プロセスにおける市民参加から協働 への発展に関する研究ーアオーレ長岡を事例として, 日本建築学会計画 系論文集, Vol. 79, No.704, pp.2231-2239, 2014.10

8）門内輝行, 西田徹：まちづくりハウスによる参加のデザインーデザイン ゲームの方法，日本建築学会（編），人間一環境系のデザイン，彰国社， pp.208-231, 1997

9) Lakoff, G. and M. Johnson : Metaphors We Live By, The University of Chicago Press, 1980 (邦訳 : レトリックと人生, 大修館書店, 1986)

10) Gentner, D. : Structure-mapping : A theoretical framework for analogy, Cognitive Science, 7, pp155-170, 1983

11）門内輝行，西田徹：まちづくりハウスによる参加のデザインーデザイン ゲームの方法，日本建築学会（編），人間一環境系のデザイン，彰国社， pp.208-231, 1997

12）門内輝行：設計方法論の展開，建築雑誌 - 研究年報，104 巻 1290 号, pp.30-31, 1989.9

13) Habraken, N. J. : Towards a new professional role, Design Studies, Volume 7, Issue 3, pp.139-143, 1986

14）アレグザンダー,C. 他：オレゴン大学の実験, 鹿島出版会, 1977

15) Becker, F.D. : Housing Messages, Douden Hutchinson \& Ross, Inc., 1977

16) Arnstein, S.R. : A Ladder of Citizen Participation, Journal of the American Institute for Planning, 1969.7

17) Goodman, N. : Ways of Worldmaking, Hackett, 1978 （邦訳：世界制作の方 法，ちくま学芸文庫, 2008)

18) Schön, D.A. : Designing: Rules, types and worlds, Design Studies, Volume 9, Issue 3, pp.181-190, 1988

19) Miller, G.A. : Images and Models, Similes and Metaphors, in Ortony, A. (ed.), Metaphor and Thought, Cambridge University Press, pp.202-250, 1979

20）門内 輝行：街並みの景観に関寸る記号学的研究，東京大学学位論文, pp.416-419, 1997

21) Hartshorne, C. and P. Weiss (eds.): Collected Papers of Charles Sanders Peirce Volume 1, Volume 2, The Belknap Press of Harvard University Press, 1978

22）池辺陽：デザインの鍵一人間・建築・方法一，丸善, 1979

23）ヒュープナー, P. : こどもたちが学校をつくるードイッ発・未来の学校, 鹿島出版会, 2008

※本研究は、平成 26 年度科学研究費補助金（特別研究員奨励費）「人間－環 境系のデザインにおける創発的プロセスに関する研究」の一部として遂行 したものである。 
A case study on BOOK WORLD DESIGN PROJECT in Rakuo elementary school of Kyoto

\author{
Suisho SAKATANI*, Yuki TAKAGI**, Yuki TAKATA*** \\ and Teruyuki MONNAI**** \\ * Researcher, Dept. of Architecture and Architectural Engineering, Graduate School of Engineering, Kyoto Universty, Dr. Eng. \\ JSPS Research Fellow \\ $* * *$ TAKENAKA CORPORATION, M. Eng.
$* * *$ Prof., Dept. of Architecture and Architectural Engineering, Graduate School of Engineering, Kyoto University, Dr.Eng.
}

\begin{abstract}
In this modern society, problems are so complex that designers have to increase their creativity and new methodologies to tackle the problems is needed to develop. This study is about the mechanism of designers' creativity and methodology for creative design. Especially we have focused on the concept of metaphor which is often discussed in many fields recently. Metaphor is defined as "understanding unknown things through known things" and we believe metaphors is related to a design process of creating unknown things.
\end{abstract}

In our previous papers, we have focused on the creativity of designers as professional design subjects but we need to expand the concept of a design subject. In other words, we have to treat other subjects such as clients and users as major design subjects and involve them to the design process. For better collaboration, it is important to design the process of consensus by design subjects and prepare languages of design for dialogue between them. In this paper, we focus on metaphors as languages of design. By using metaphors, design subjects make their worlds, which is N.Goodman's term, for the design object. We make a hypothesis that through this process design subjects can understand and feel empathy for design object. As a result, they can make consensus and collaborate with each other well.

Against this background, we organized the project of "BOOK WORLD DESIGN PROJECT in Rakuo Elementary School of Kyoto". In this project we collaborated with 6th-grade students in the school and designed the library space in Rakuo Elementary School, "Book World". This project contains 4 workshops many students participated in. In the early phase of the project, students generated a lot of ideas for new "Book World" they want using the great scale architectural models. In the latter phase, we made 3 alternatives of new Book World referring students' ideas. These alternatives are generated through the 3 worlds based on 3 metaphors, "Nature and Grass", "Universe and Future" and "Life and Living". Students understand the alternatives through the worlds, and generate a lot of additional ideas to improve the Book World. Through this process, 3 plans were integrated to a plan and the new Book World were completed at last.

In this design process, we kept a log of our and students' design. By analyzing the log, we tried to clarify and how metaphors or the worlds based on the metaphors effected on the thinking process of students and their motivation as major design subjects. The results are shown as below.

1) Effect on the students' creation and their creativity

Portraying the world on alternatives of a design object, students can create a lot of ideas of a design object in the process of thinking of the world generating several concepts and expanding the worlds.

2) Effect on the students' motivation as major design subjects

That the worlds are based on metaphors means that students need to reason what the metaphors mean in order to imagine and understand the world. From the view point of this cognitive mechanism of metaphor, we discussed the possibility of metaphor for effecting on the motivation of design subjects and collaboration by many design subjects. 